\title{
Equilibrium in the System of Glauconite - Aqueous Solution of Cefepime Hydrochloride
}

\author{
(c) 2019 T. A. Krysanova ${ }^{\bowtie}$, D. L. Kotova, Mohammed T. Bestoon \\ Voronezh State University \\ 1, Universitetskaya pl., 394018 Voronezh, Russian Federation
}

\begin{abstract}
The patterns of immobilization of cefepime hydrochloride on glauconite at a temperature of $295 \mathrm{~K}$ are established. The isotherm of sorption of cefepime hydrochloride from dilute solutions is described using the Langmuir theory. The values of the maximum capacity of the monolayer and the coefficient of the sorption equilibrium for cefepime hydrochloride are calculated. It is revealed that the monolayer binding of the antibiotic to glauconite is the result of an equivalent exchange with the extra-frame cations of the sorbent. The polymolecular nature of the sorption may be due to the formation of cefepime hydrochloride associates due to hydrogen bonds.
\end{abstract}

Keywords: sorption, glauconite, cefepime hydrochloride.

\section{INTRODUCTION}

The studies of the pharmacological direction [1-5] presented in the literature on the immobilization of biologically active substances on natural sorbents indicate an increased interest in studying the properties of enterosorbents based on aluminosilicates which can be used as effective carriers of prolonged action pharmaceutical preparations. Among natural aluminosilicates, glauconite, a sorbent with layered structure, developed surface, high adsorption capacity, and possibility of chemical modification [6, 7] can be considered promising for use in medicine and biotechnology. One of the groups of drugs - antibiotics are cephalosporins of the 4 th generation. Included in this group cefepim is characterized by a wide spectrum of action, low toxicity, favorable pharmacinetics, compatibility with other antibacterial agents and is widely used for the treatment of severe infections in clinical therapy $[8,9]$.

The aim of this work was to study the sorption ability of glauconite with respect to cefepime hydrochloride.

\section{EXPERIMENT}

The object of the study was chosen a clayey layered mineral - glauconite, deposits of the southwest of the Voronezh anteclise [10]. The phase com-

Tatiana A. Krysanova, e-mail: takrys@yandex.ru position of the studied glauconite is represented by alternating-layer mineral (ALM) of the illis-smectite (I-S) series with a layer ratio of 20:80, as well as 50:50 (swelling component). The elemental analysis of the sorbent (Table 1) indicates the presence of water molecules and exchange cations $\mathrm{K}^{+}, \mathrm{Mg}^{2+}$, and $\mathrm{Ca}^{2+}$ in the interlayer space. The total pore volume is $0.31 \mathrm{~cm}^{3} / \mathrm{g}$, and the average pore diameter is $5.7 \mathrm{~nm}$ [11].

We used the antibiotic - cefepime hydrochloride (1-[[7-[[(2-amino-4-thiazolyl) (methoxyimino )acetyl]amino] - 2 - carboxy - 8 - oxo - 5 - thia - 1 azabicyclo [4.2.0]oct-2-en-3-yl]methyl]-1-methylpyrrolidinium hydrochloride) by Hightechhealthcare (India). The structural formula of cefepime is shown in Fig. 1.

Sorption equilibrium in the system glauconite (fraction $0.02-0.04 \mathrm{~mm}$ ) - aqueous solution of cefepime hydrochloride was studied at a temperature of $295 \mathrm{~K}$ under static conditions by the method of variable concentrations [12]. The interval of antibiotic concentrations used was 0.05$4.0 \mathrm{mmol} / \mathrm{l}$. A weighed portion of the sorbent weighing $0.10 \pm 0.0002 \mathrm{~g}$ in an air-dry state was brought into contact with $200.0 \mathrm{ml}$ of an aqueous solution of the preparation of the known concentration and kept under constant stirring for 2 hours at a given temperature. The time to establish equilibrium in the studied system was determined from the 
Table 1. Elemental composition of natural glauconite

\begin{tabular}{|c|c|c|c|c|c|c|c|c|c|c|c|c|}
\hline \multirow{2}{*}{ Sample } & \multicolumn{10}{|c|}{ Element, atom. \% } & \multirow{2}{*}{ Total } \\
\cline { 2 - 12 } & $\mathrm{Na}$ & $\mathrm{Mg}$ & $\mathrm{Al}$ & $\mathrm{Si}$ & $\mathrm{K}$ & $\mathrm{Ca}$ & $\mathrm{Cr}$ & $\mathrm{Fe}$ & $\mathrm{Ti}$ & $\mathrm{Cu}$ & $\mathrm{S}$ & \\
\hline Glt-Nat & - & 1.54 & 3.66 & 15.86 & 1.74 & 0.42 & 0.05 & 4.48 & 0.11 & - & 0.05 & 100 \\
\hline
\end{tabular}<smiles>CO/N=C(\C(=O)N[C@@H]1C(=O)N2C(C(=O)[O-])=C(C[N+]3(C)CCCC3)CS[C@H]12)c1csc(N)n1</smiles>

Fig. 1. Chemical formula of cefepime hydrochloride.

Sorption equilibrium in the system glauconite (fraction 0.02-0.04 $\mathrm{mm}$ ) - aqueous

preliminary kinetic experiment. The sorption of the antibiotic was carried out from solutions with $\mathrm{pH}=4.2$, in which cefepime was present in the solution mainly in the form of a cation.

The equilibrium phases were separated by filtration, the filtrate was analyzed for antibiotic content by means of a spectrophotometric method on the Shimadzu UV-1800 spectrophotometer under the analytical wavelength of $\lambda=257 \mathrm{~nm}(\varepsilon=7951 \mathrm{l} /(\mathrm{mol} \cdot \mathrm{cm})$, $\mathrm{Sr}=0.003)$. The amount of the sorbed preparation was determined by means of difference in the solution concentrations before and after contact with the sorbent. The content of $\mathrm{K}^{+}$ions in the equilibrium solution was determined by means of flame photometry (error $2.0 \%$ ), $\mathrm{Ca}^{2+}$ and $\mathrm{Mg}^{2+}$ ions by means of complexometry (error $0.4 \%$ ). The experimental results were processed by means of mathematical statistics with a confidence coefficient of 0.95 .

IR spectra of glauconite before and after contact with the aqueous solution of cefepime hydrochloride were recorded on the Bruker Equinox 55 spectrometer with Fourier transform in the diffusion reflection mode in the frequency range 400$4000 \mathrm{~cm}^{-1}$ with a resolution of $4 \mathrm{~cm}^{-1}$ at a temperature of $298 \mathrm{~K}$. The method error is $3 \%$. The literature $[13,14]$ was used to interpret the obtained IR spectra.

\section{RESULTS AND DISCUSSION}

The immobilization of biologically active substances (in particular, antibiotics) on aluminosilicates is a complex specific process, including both the possibility of ion exchange of extra-frame cations with antibiotic cations, and the appearance of additional polymolecular interactions in the system. The interfacial distribution of cefepime hydrochlo- ride in the system glauconite - aqueous solution of antibiotic is shown in Fig. 2.

According to the IUPAC nomenclature, isotherms can be attributed to type IV, according to Giles classification, they correspond to the S-form [15], which indicates the multilayer nature of the antibiotic fixation on glauconite.

When the drug is sorbed from dilute solutions (less than $0.8 \mathrm{mmol} / \mathrm{l}$ ), the nature of the isotherm is linear. Then a plateau is observed, which suggests a monolayer fixation of the antibiotic on the active groups of glauconite, which are the electronegative centers of the alumina-oxygen frame of the sorbent [16]. The amount of monolayer-fixed cefepime is equivalent to the total amount of extra-frame cations $\left(\mathrm{K}^{+}, \mathrm{Ca}^{2+}\right.$ and $\left.\mathrm{Mg}^{2+}\right)$ transferred to

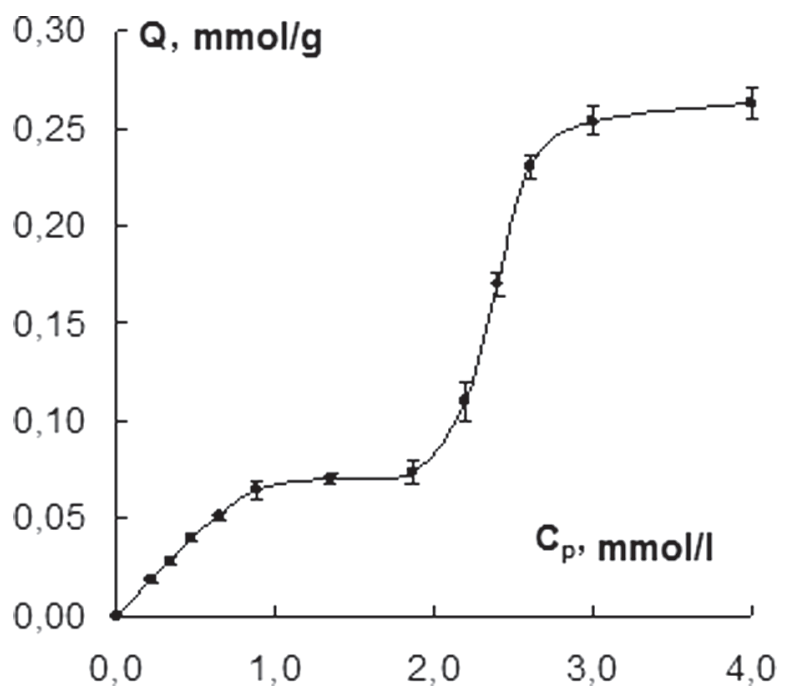

Fig. 2. Isotherm of sorption of cefepime hydrochloride from an aqueous solution on glauconite at $295 \mathrm{~K}$ 
the equilibrium solution. Consequently, the formation of a monomolecular layer proceeds in accordance with the equivalent exchange mechanism. The $\mathrm{K}^{+}$-ion, which is the predominant off-frame cation of glauconite plays the main role in the ion exchange [11].

The sorption of cefepime hydrochloride on glauconite is characterized by the appearance of additional absorption bands on the IR spectrum of the sorbent and the shift of the maxima of the main absorption bands. The fixation of cefepime on the active centers of glauconite in accordance with the mechanism of equivalent exchange with extraframe metal cations is manifested in the shift in the frequencies of stretching vibrations corresponding to $\mathrm{Si}-\mathrm{O}-(\mathrm{Al})$ groups of glauconite $(1106 \rightarrow 1062$ and $1022 \rightarrow 1010 \mathrm{~cm}^{-1}$ ) and $\mathrm{NH}$-antibiotic groups $(1543 \rightarrow 1520)$ to the low frequency area of the spectrum compared with the oscillation frequency in the spectra of the initial sorbent and pure antibiotic. The presence of sorbed cefepime in the IR spectrum while maintaining its biological activity is also manifested in the appearance of an absorption band at $1774 \mathrm{~cm}^{-1}$, corresponding to vibrations of the group $\mathrm{C}=\mathrm{O}$ in the $\beta$-lactam ring of the antibiotic $[13,14]$.

After the formation of the monolayer, with an increase in the solution concentration of the antibiotic to above $2.0 \mathrm{mmol} / \mathrm{l}$, a sharp increase in the sorption parameter is observed without changing the ion-exchange component of the sorption process. The maximum sorption capacity of the sorbent for cefepime equal to $0.26 \mathrm{mmol} / \mathrm{g}(126 \mathrm{mg} / \mathrm{g})$ was revealed. Probably, adsorbing on the negative centers of the glauconite framework, the cefepime ions become new sorption centers for the next lay- ers of the antibiotic. Multilayer sorption of cefepime is possible as a result of the formation of its associates due to hydrogen bonds [15].

In the IR spectrum of the sorbent containing the antibiotic, absorption bands are observed in the 1380 and $1675 \mathrm{~cm}^{-1}$ areas, which are responsible for the symmetric and asymmetric stretching vibrations of the COO-group participating in the formation of the hydrogen bond. The formation of associates due to the hydrogen bond is also indicated by the shift to the low-frequency area of the absorption bands at 3070 and $1520 \mathrm{~cm}^{-1}$, which are responsible for stretching and deformation vibrations of the $\mathrm{NH}$ group.

To determine the quantitative characteristics of the sorption of the antibiotic on glauconite in the concentration range responsible for the formation of the monolayer of the preparation, Langmuir, Freindlich, and Redlich-Peterson models were used [17-19]. To determine the values of the constants included in the equations of the Langmuir and Freindlich isotherms, linearized equations of these models were used. The values of the parameters included in the equations of the models and the correlation coefficients are presented in Table 2.

The obtained values of the correlation coefficients $\left(R^{2}\right)$ indicate that the sorption of cefepime as a result of equivalent exchange with extra-frame cations is most likely described by the Langmuir equation. The applicability of the model in this case indicates the equivalence of the active centers and the uniformity of the surface of glauconite. The value of the parameter $\beta$ in the Redlich-Peterson equation is close to 1 , which confirms that the sorption of the antibiotic from the diluted solutions proceeds according to the Langmuir mechanism.

Table 2. Values of sorption parameters calculated with use of Langmuir, Freindlich and Redlich-Peterson equations

\begin{tabular}{|c|c|c|c|c|c|}
\hline \multicolumn{6}{|c|}{ Langmuir model } \\
\hline \multirow{2}{*}{ Cefepime } & \multicolumn{2}{|c|}{$K_{L}, \mathrm{dm}^{3} /$ mole } & \multicolumn{2}{|c|}{$\overline{Q_{\infty}}, \mathrm{mmol} / \mathrm{g}$} & $R^{2}$ \\
\hline & \multicolumn{2}{|l|}{2.02} & \multicolumn{2}{|c|}{0.09} & 0.99 \\
\hline \multicolumn{6}{|c|}{ Freindlich model } \\
\hline \multirow{2}{*}{ Cefepime } & \multicolumn{2}{|c|}{$K_{P}\left(\mathrm{dm}^{3}\right)^{1 / \mathrm{n}}(\mathrm{mmol})^{1-1 / n} / \mathrm{g}$} & \multicolumn{2}{|c|}{$n$} & $R^{2}$ \\
\hline & \multicolumn{2}{|l|}{2.60} & \multicolumn{2}{|c|}{2,00} & 0.94 \\
\hline \multicolumn{6}{|c|}{ Redlich-Peterson model } \\
\hline \multirow{2}{*}{ Cefepime } & $K_{R}, \mathrm{dm}^{3} / \mathrm{g}$ & & $\mathrm{Ool}^{\beta}$ & $\beta$ & $R^{2}$ \\
\hline & 1.08 & & & 0.99 & 0.95 \\
\hline
\end{tabular}

where $\bar{Q}_{\infty}$ - maximum amount of the sorbed preparation (monolayer capacity), mmol/g; $K_{L}$ - sorption equilibrium constant, $\mathrm{dm}^{3} / \mathrm{mmol} ; n$ - Freundlich isotherm constant $K_{F}$ - Freundlich isotherm constant (sorption capacity) $\left(\mathrm{dm}^{3}\right)^{1 / n}(\mathrm{mmol})^{1-1 / \mathrm{n}} / \mathrm{g} ; a_{R}$ and $K_{R}$ - Redlich-Peterson isotherm constants, $\left(\mathrm{dm}^{3}\right)^{\beta} / \mathrm{mmol}^{\beta}$ и $\mathrm{dm}^{3} / \mathrm{g}$ respectively; $\beta$ - constant, the value of which should lie in the interval $0<\beta<1$. 
The equilibrium distribution coefficient that determines the selectivity of glauconite to the antibiotic in the entire range of the studied solution concentrations (Fig. 3) was calculated.

In the initial section of the curve, when the monolayer is formed, a sharp decrease in the distribution coefficient is observed, and then its values practically do not change. Decrease in the distribution coefficient with increasing concentration may be due to additional interactions in the system studied, leading to steric restrictions [20].

\section{CONCLUSION}

The patterns of sorption of cefepime hydrochloride on glauconite at a temperature of $295 \mathrm{~K}$ have been revealed. It is shown that the monolayer binding of the antibiotic to glauconite occurs as a result of equivalent exchange with extra-frame cations of the sorbent, and the polymolecular nature of sorption is associated with the formation of cefepime hydrochloride associates due to hydrogen bonds. It has been revealed that the sorption of the antibiotic from dilute solutions is described by the Langmuir model with maximum probability. The sorption parameters have been calculated using the linearized Langmuir, Freindlich, RedlichPeterson equations and the equilibrium distribution coefficient.

\section{CONFLICT OF INTEREST}

The authors declare the absence of obvious and potential conflicts of interest related to the publication of this article.

\section{REFERENCES}

1. Kevadiya Bravesh D., Ghanshyam V. Joshi, Hasmukh A. Patel, et al. Montmorillonite-alginate nanocomposites as a drug delivery system: intercalation and in vitro release of vitamin $B_{1}$ and vitamin $B_{6}$. Journal of Biomaterials Aplications, 2010, v. 25(2), pp. 161177. DOI: https://doi.org/10.1177/0885328209344003

2. Farias T., Rabdel Ruiz-Salvador A., Lya Velazco, et al. Preparation of natural zeolitic supports for potential biomedical applications. Materials Chemistry and Physics, 2009, v. 118, pp. 322-328. DOI: https:// doi.org/10.1016/j.matchemphys.2009.07.054

3. Chernova R. K., Venig S. B., Naumova G. N., et al. Sorption of tetracycline and its degradation products by glauconite. Scientific almanac, 2015, no. 7, pp. 930-934. DOI: https://doi.org/0.17117/na.2015. 07.930

4. Vlasova N. N. Interaction of highly dispersed silica with some medicinal substances. Surface, 2016, v. 8(23), pp. 236-247. DOI: https://doi.org/10.15407/ surface.2016.08.236

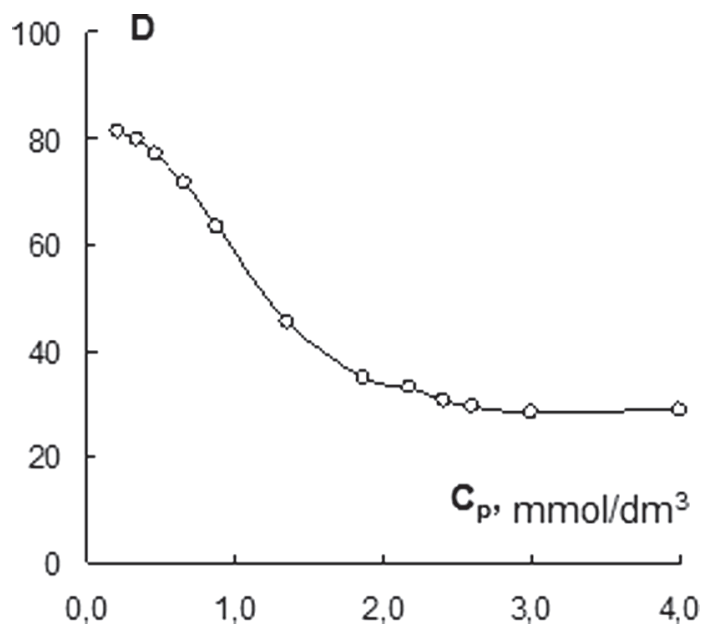

Fig. 3. Dependence of the distribution coefficient of cefepime hydrochloride from its equilibrium concentration

5. Stavinskaya O. N., Laguta I. V. The properties of silica-gelatin composites. Russian Journal of Physical Chemistry A, 2010, v. 84(6), pp. 1045-1048. D OI: https://doi.org/10.1134/s0036024410060270

6. Fiziko-khimicheskiye i mediko-biologicheskiye svoystva prirodnykh zeolitov [Physicochemical and biomedical properties of natural zeolites] / Ed. by Z. V. Belousova. Novosibirsk, Izd-vo un-ta geologii i geofiziki, 1990, 70 p. (in Russ.)

7. Breck D. W. Zeolite molecular seves: Structure, Chemistry and Use. Wiley-Interscience, New York, $1974,771 \mathrm{p}$.

8. Egorov N. S. Osnovy ucheniya ob antibiotikakh [Fundamentals of the doctrine of antibiotics]. Moscow, Nauka Publ., 2004, 528 p. (in Russ.)

9. Yakovlev P. V. Ciprofloxacin in the treatment and prophylaxis of surgikal infections. Antibiotiki i khimioterapiya, 1999, v. 44(7), pp. 32-37. (in Russ.)

10.Zhabin A. V., Savko A. D. Glaukonity Voronezhskoy anteklizy. Ocherki po regionalnoy geologii [Glauconites of the Voronezh anteclise. Essays on regional Geology]. Saratov, Nauka Publ., 2008, pp. 48-56. (in Russ.)

11. Novikova L. A., Belchinskay L. I., Krupskaya V. V., et al. Effect of acid and alkaline treatment on physical and chemical properties of natural glauconite surface. Sorption and Chromatographic Processes, 2015, v. 15(5), pp. 730-740. Available at: https://doi.org/10.17308/sorpchrom.2015.15/327 (accessed 23.10.2019) (in Russ.)

12. Polyanskiy N. G.. Gorbunov V. G.. Polyanskaya N. L. Research methods of ion exchangers. Moscow, Khimiya Publ., 1976, 208 p. (in Russ.)

13. Nakanisi K. Infrared spectroscopy and structure of organic compounds. Moscow, Mir Publ., 1987, 220 p. (in Russ.)

14. Bekker Yu. Spektroskopiya [Spectroscopy]. Moscow, Tekhnosfera Publ., 2009, 528 p. (in Russ.) 
15. Sing K. S. W., Everett D. H., Haul R. A. W. Reporting physisorption data for gas/solid systems with special reference to the determination of surface area and porosity. Pure and Applied Chemistry, 1985, v. 57(4), pp. 603-619. DOI: https://doi.org/10.1351/ pac198557040603

16. Kotova D. L., Fam Tkhi Gam, Krysanova T. A., et al. Description of pyridoxine hydrochloride sorption isotherm on clinoptilolite tuff. Sorption and Chromatographic Processes, 2014, v. 14(4), pp. 572-577. Available at: http:// www.sorpchrom.vsu.ru/articles /20140404. pdf (accessed 23.10.2019) (in Russ.)

УДК 543.183.7

DOI: https://doi.org/10.17308/kcmf.2019.21/2189

Поступила в редакцию 24.10.2019

Подписана в печать 15.11.2019
17. Langmuir I. The Constitution and fundamental properties of solids and liquids. J.Am. Chem. Soc., 1917, v. 39(9), pp. 1848-1906. DOI: https://doi.org/10.1021/ ja02254a006

18. Freundlich H. M. F. Over the adsorption in solution. J. Phys. Chem., 1906, v. 57, pp. 385-447.

19. Redlich O. A., Peterson D. L. Useful adsorption isotherm. J. Phys. Chem., 1959, v. 63(6), pp. 1024-1025. DOI: https://doi.org/10.1021/j150576a611

20. Pyul'man B. Intermolecular interaction: from diatomic molecules to biopolymers, Moscow, Mir Publ., 1981, 592 p. (in Russ.)

\title{
Равновесие в системе глауконит-водный раствор гидрохлорида цефепима
}

\author{
(c) 2019 Т. А Крысанова ${ }^{\bowtie}$ Д. Л. Котова, Мохаммед Т. Бестун \\ Воронежский государственный университет \\ Университетская пл., 1, 394018 Воронеж, Российская Федерация
}

\begin{abstract}
Аннотация
Изучение сорбционной способности природных алюмосиликатов разной химической природы по отношению к лекарственным препаратам (в частности, к антибиотикам) для повышения их стабильности и эффективности применения является одной из актуальных проблем современной химии сорбционных процессов.

Выявлены закономерности сорбции антибиотика (гидрохлорида цефепима) из водного раствора на глинистом слоистом минерале (глауконите) при температуре 295 К. Установлено, что в мономолекулярной сорбции цефепима на глинистом алюмосиликате основная роль принадлежит механизму эквивалентного обмена внекаркасных катионов на катионы цефепима за счет электростатического взаимодействия между электроотрицательными центрами алюмокислородного каркаса глауконита и активными группами антибиотика с положительным зарядом. Показано, что полимолекулярный характер сорбции антибиотика проявляется в образовании ассоциатов цефепима за счет водородных связей, когда закрепленные на сорбенте молекулы антибиотика выступают в роли новых активных центров сорбции. Данные подтверждены ИК-спектроскопическим исследованием.

Изотерма сорбции гидрохлорида цефепима на глауконите описана с применением уравнений Ленгмюра, Фрейндлиха и Редлиха - Петерсона. Выявлено, что сорбция антибиотика из разбавленных растворов с максимальной вероятностью описывается моделью Ленгмюра.

С помощью данной модели рассчитаны величины предельной емкости монослоя и значения коэффициента сорбционного равновесия для гидрохлорида цефепима. Рассчитан равновесный коэффициент распределения, свидетельствующий о селективности глауконита к антибиотику во всей области исследуемых концентраций раствора.
\end{abstract}

Ключевые слова: сорбция, глауконит, гидрохлорид цефепима.

Крысанова Татьяна Анатольевна, e-mail: takrys@yandex.ru 
Крысанова Татьяна Анатольевна - к. х. н., доцент кафедры аналитической химии, Воронежский государственный университет, Воронеж, Российская Федерация; e-mail: takrys@yandex. ru. ORCID iD: https://orcid.org/0000-0003-17206358.

Котова Диана Липатьевна - д. х. н., профессор кафедры аналитической химии, Воронежский государственный университет, Воронеж, Российская Федерация; ORCID iD: https://orcid. org/0000-0002-6060-088X.

Мохаммед Т. Бестун - магистрант кафедры аналитической химии, Воронежский государственный университет, Воронеж, Российская Федерация.
Tatiana A. Krysanova - Cand. Sci. (Chem.), Associate Professor, Department of Analytic Chemistry, Voronezh State University, Voronezh, Russian Federation; e-mail: takrys@yandex.ru. ORCID iD: https://orcid.org/0000-0003-1720-6358.

Diana L. Kotova - Dr. Sci. (Chem.), Full Professor, Department of Analytical Chemistry, Voronezh State University, Voronezh, Russian Federation; ORCID iD: https://orcid.org/0000-0002-6060-088X.

Mohammed T. Bestoon - undergraduate, Department of Analytical Chemistry, Voronezh State University, Voronezh, Russian Federation. 